\title{
Changes of cell growth and magnetosome biomineralization in Magnetospirillum magneticum AMB-1 after ultraviolet-B irradiation
}

\author{
Yinzhao Wang ${ }^{1,2}$, Wei Lin ${ }^{1,2}$, Jinhua Li ${ }^{1,2}$ and Yongxin Pan ${ }^{1,2 *}$ \\ Biogeomagnetism Group, Paleomagnetism and Geochronology Laboratory, Key Laboratory of the Earth's Deep Interior, Institute of Geology and Geophysics, \\ Chinese Academy of Sciences, Beijing, China \\ ${ }^{2}$ France-China Bio-Mineralization and Nano-Structures Laboratory, Chinese Academy of Sciences, Beijing, China
}

\author{
Edited by: \\ Damien Faivre, Max Planck Society, \\ Germany \\ Reviewed by: \\ Dennis A. Bazylinski, University of \\ Nevada, at Las Vegas, USA \\ Ulysses Lins, Universidade Federal \\ do Rio de Janeiro, Brazil

\section{*Correspondence:} \\ Yongxin Pan, Institute of Geology \\ and Geophysics, Chinese Academy \\ of Sciences, 19 BeiTuCheng W Rd., \\ Beijing 100029, China \\ e-mail:yxpan@mail.iggcas.ac.cn
}

Effects of ultraviolet radiation on microorganisms are of great interest in field of microbiology and planetary sciences. In the present study, we used Magnetospirillum magneticum AMB-1 as a model organism to examine the influence of ultraviolet-B (UV-B) radiation on cell growth and magnetite biomineralization of magnetotactic bacteria (MTB). Live AMB-1 cells were exposed to UV-B radiation for 60, 300 and $900 \mathrm{~s}$, which correspond to radiation doses of $120 \mathrm{~J} / \mathrm{m}^{2}, 600 \mathrm{~J} / \mathrm{m}^{2}$, and $1800 \mathrm{~J} / \mathrm{m}^{2}$, respectively. After irradiation, the amounts of cyclobutane pyrimidine dimers (CPD) and reactive oxygen species (ROS) of the cells were increased, and cell growth was stunted up to $\sim 170 \mathrm{~h}$, depending on the UV-B radiation doses. The UV-B irradiated cells also produced on average more magnetite crystals with larger grain sizes and longer chains, which results in changes of their magnetic properties.

Keywords: magnetotactic bacteria, ultraviolet-B radiation, cell growth, microbial biomineralization, rock magnetic measurement

\section{INTRODUCTION}

Solar ultraviolet radiation (wavelengths $10-400 \mathrm{~nm}$ ) fluctuation is proposed as one of the most important selective pressures on the evolution of life on Earth (Cockell, 1998; Garcia-Pichel, 1998; Häder et al., 2007; Sinha and Häder, 2008; Weigand and Sundin, 2012). Although the stratospheric ozone protects organisms on Earth from UV radiation exposure (Solomon, 1999), the ozone layer can be stripped away by solar wind when the strength of the Earth's magnetic field is low. For instance, during geomagnetic excursion or polarity reversal, the field is thought to $20 \%$ of its typical strength (Reid and Isaksen, 1976; McKenzie et al., 2003; Glassmeier and Vogt, 2010; Stadelmann et al., 2010; Valet and Valladas, 2010). Consequently, the depletion of the ozone layer will lead to increased penetration of harmful radiation to the Earth's surface, which may affect aquatic ecosystems (Hargreaves, 2003; Wulff et al., 2008). UV-C radiation (wavelengths $10-280 \mathrm{~nm}$ ) can normally be absorbed by the ozone layer, but UV-B (wavelengths $280-320 \mathrm{~nm}$ ) and UV-A radiation (wavelengths $320-400 \mathrm{~nm}$ ) can reach the biosphere and influence living organisms (Zepp et al., 1998; Zenoff et al., 2006; Konhauser et al., 2007; Santos et al., 2013). In addition to enhancing production of intracellular reactive oxygen species (ROS) (similar to the UV-A radiation), UV-B radiation could directly damage DNA in organisms and thus should be more detrimental to organism health (Qiu et al., 2005b; Hernandez et al., 2006; Santos et al., 2013).

Microorganisms are the earliest known species to have appeared on Earth. Various microorganisms could form minerals and thus can leave fossil records that have been used to trace early life on Earth and other planets such as Mars (Li et al., 2013a). However, how UV radiation influences the microbial biomineralization and the formation of fossil biominerals or mineral-encrusted cells (i.e., microfossils) is still poorly understood (Cockell, 1998; Garcia-Pichel, 1998; Häder et al., 2007; Singh et al., 2010). Recent investigations on aquatic bacterial isolates have revealed that UV-B radiation could lead to DNA lesion and cellular oxidative stress (Agogué et al., 2005; Santos et al., 2011, 2012, 2013; Matallana-Surget et al., 2012; Singh et al., 2012). On the other hand, some microorganisms have evolved strategies to mitigate such irradiation damage (Sinha and Häder, 2008; Schmidt et al., 2009; Weigand and Sundin, 2009; Singh et al., 2010; Weigand et al., 2011). For example, in vitro biomineralization of iron-silica biominerals of filamentous cyanobacterium Calothrix help the bacteria efficiently coping with UV irradiation. Compared with non-mineralized bacteria, the mineralized bacteria represent remarkable resistance to UV irradiation as revealed by the rates of photosynthesis, chlorophyll-a content, and phycocyanin autofluorescence (Phoenix et al., 2001). Cyanobacterium Lyngbya majuscula was found to produce chemical compounds that were able to absorb UV radiation and synthesize an incrassate cell sheath under enhanced UV-B irradiation (Mandal et al., 2011).

Magnetotactic bacteria (MTB) are able to synthesis single domain (SD) magnetic particles within intracellular membrane organelles called magnetosome (Bazylinski and Frankel, 2004; Faivre and Schüler, 2008). The magnetosome, usually arranged in chain(s), facilitate MTB to navigate along the Earth's magnetic field and efficiently find the optimal living conditions in aquatic and sedimentary environments, a process known as magnetotaxis (Bazylinski and Frankel, 2004; Pan et al., 2009). After MTB die and are buried, the magnetosome crystals can be preserved as 
fossil biominerals (magnetofossils), which are potential geological records for paleoenvironmental and paleomagnetic information, as well as biosignatures for searching early life on Earth and extraterrestrial life (Petersen et al., 1986; Chang and Kirschvink, 1989; McKay et al., 1996; Yamazaki and Kawahata, 1998; Arató et al., 2005; Pan et al., 2005; Kopp and Kirschvink, 2008; Paterson et al., 2013). Previous studies have demonstrated that environmental factors, such as salinity, temperature, the strength of geomagnetic field, oxygen and iron resource, can influence the overall diversity of MTB communities in nature and the compositional, physical, and magnetic features of magnetosomes (e.g., Lins et al., 2007; Faivre et al., 2008; Lin et al., 2011, 2013a,b; Li and Pan, 2012; Wang et al., 2013). However, to our knowledge, the influence of UV radiation on MTB has not been studied yet, although it is of particular interest for better understanding the evolution of magnetotaxis in early history of Earth. During a geomagnetic excursion or polarity reversal, where the dipolar geomagnetic field was weak and the UV radiation was strong, how MTB respond to the environmental changes also remains unknown. In the present study, we have investigated the effects of UV-B radiation on cell growth and magnetite biomineralization of Magnetospirillum magneticum AMB-1. Possible relationships between magnetosome formation and UV-B irradiation are discussed.

\section{MATERIALS AND METHODS PREPARATION OF CELL AND GROWTH CONDITIONS}

A facultative anaerobic MTB strain Magnetospirillum magneticum AMB-1 (ATCC700264) was used in this study. In all experiments, cells were cultivated in the magnetic spirillum growth medium (MSGM) (Blakemore et al., 1979). This medium (1 L) contains $5 \mathrm{ml}$ of Wolfe's mineral solution, $10 \mathrm{ml}$ of Wolfe's vitamin solution, $0.68 \mathrm{~g}$ of potassium phosphate, $0.12 \mathrm{~g}$ of sodium nitrate, $0.05 \mathrm{~g}$ of sodium acetate, $0.035 \mathrm{~g}$ of ascorbic acid, $0.37 \mathrm{~g}$ of tartaric acid, $0.37 \mathrm{~g}$ of succinic acid, and $50 \mu \mathrm{M}$ of ferric quinate. In order to obtain a uniform genotype strain, originally activated AMB-1 cells were plated onto MSGM agar plate for 7 days, single clone was picked up and enlarged cultivated for the following studies. Non-magnetic AMB-1 cells were obtained by growing cells under $220 \mathrm{rpm}$ rotation at $26^{\circ} \mathrm{C}$ with free air exchange. The non-magnetic cells were then inoculated equally to twelve UV-B penetrable quartz bottles. Each bottle contained $300 \mathrm{~mL}$ of MSGM culture medium and was incubated under the same cultivation condition. When the cell density reached $\sim 1.0 \times 10^{7}$ cells/ml at early exponent phase, the bottle was used for the irradiation experiment.

\section{SOURCE OF UV-B RADIATION AND IRRADIATION EXPERIMENT}

The irradiation experiment system is shown in Figure 1. UV-B radiation was obtained from USHIO ultraviolet lamps (USHIO America, USA). The lamps were coated with special blended phosphor to emit radiation peaking at $306 \mathrm{~nm}$. The radiation intensity of light source was measured by a double-channel UV$B$ radiometer with a detective range between 275 and $330 \mathrm{~nm}$ (Beijing Normal University, China). The double-sided UV-B irradiation system with an averaged UV-B radiation intensity of 2.0 $\mathrm{W} / \mathrm{m}^{2}$ was used to carry out the experiment. The irradiation

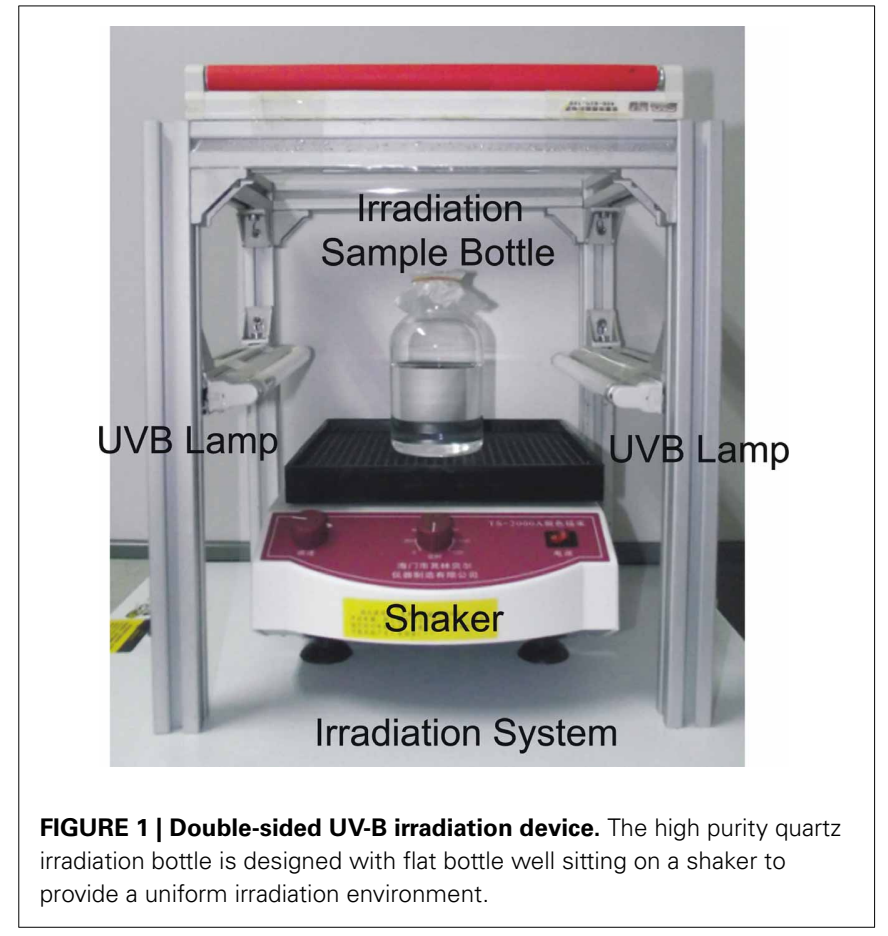

bottles containing AMB-1 inoculations were exposed to UV-B radiation for 60,300 , and $900 \mathrm{~s}$, which were equivalent to radiation doses of 120,600 , and $1800 \mathrm{~J} / \mathrm{m}^{2}$, respectively. To ensure even exposure the bottles were rotated at $50 \mathrm{rpm}$ during irradiation. Non-irradiated cell samples (bottles covered with aluminum foils) were taken as experimental control. All twelve irradiation bottles with AMB-1 cells were divided into the four different experiment groups with tripled repeats of each UV-B radiation condition.

After the irradiation, $10 \mathrm{~mL}$ of cells were immediately taken from the bottle for cyclobutane pyrimidine dimers (CPD) and ROS analyses. The rest of the culture was centrifuged at $4^{\circ} \mathrm{C}$ $6000 \mathrm{rpm}$ for $10 \mathrm{~min}$. Then the cells of each sample were washed by $0.9 \% \mathrm{NaCl}(\mathrm{wt} / \mathrm{vol})$ and inoculated into $500-\mathrm{mL}$ fresh MSGM medium, respectively under anaerobic condition in the dark. The cell growth of each group was examined through the optical density at $600 \mathrm{~nm}\left(\mathrm{OD}_{600}\right)$. As the sample reached stationary phase for $40 \mathrm{~h}$, the cells were harvested for cell morphology, magnetosome crystal, and magnetic analyses.

\section{DETERMINATION OF RELATIVE CPD PRODUCTION}

The relative CPD production was used to assess the DNA damage in the UV-B irradiated cells. The DNA was extracted using TIANamp Bacteria DNA Kit (TIANGEN, China). The concentrations of DNA were determined by the absorbance at $260 \mathrm{~nm}$ and calculated by Lambert-beer law. In order to generate a uniform comparison, each DNA sample was diluted to $1 \mu \mathrm{g} / \mathrm{mL}$. For enzyme-linked immunosorbent assay, first, $0.04 \%$ protamine sulfate was coated to a polyvinylchloride flat-bottomed microtitre plate for $2 \mathrm{~h}$ at $37^{\circ} \mathrm{C}$. Fifty microliters of the denatured DNA were put into the plate wells and incubated for $1 \mathrm{~h}$ at $90^{\circ} \mathrm{C}$. The plate was washed 5 times by phosphate-buffered saline with 
twain (PBS-T) after drying. Then $200 \mu \mathrm{L}$ of $3 \%$ BSA were add to each well and incubated at $37^{\circ} \mathrm{C}$ for $30 \mathrm{~min}$ and washed as described above. After blocking, $100 \mu \mathrm{L}$ anti-thymine dimer antibody [H3] (abcam, USA) were added and incubated at $37^{\circ} \mathrm{C}$ for $1 \mathrm{~h}$, then washed again. The plate with $100 \mu \mathrm{L} /$ well HRP affinipure goat anti-mouse IgG (EarthOx, USA) was incubated at $37^{\circ} \mathrm{C}$ for $30 \mathrm{~min}$. Then, the plate was washed 3 times with PBS$\mathrm{T}$ and 2 times with citrate-phosphate buffer of $\mathrm{pH}$ 5.0. Finally, $100 \mu \mathrm{L}$ of o-phenylene diamine and $0.007 \%$ hydrogen peroxide in citrate-phosphate buffer were then added to each well and incubated for $30 \mathrm{~min}$ at $37^{\circ} \mathrm{C}$. Fifty microliters of $2 \mathrm{~mol} / \mathrm{L} \mathrm{H}_{2} \mathrm{SO}_{4}$ were added to stop the reactions. The absorbance was then read at $490 \mathrm{~nm}$ using a microplate reader (SynergyTMH4, BioTek, USA) to determine the CPD photoproduct. The relative generations of CPD were normalized by the absorbance of the blank control.

\section{DETECTION OF ROS GENERATION}

The generation of ROS was analyzed by using DCFH-DA method based on previous report (He and Häder, 2002). DCFH-DA can be taken by cell and hydrolyzed to DCFH, which can not pass through cell membranes and is trapped within cell. Intracellular ROS can oxidize nonfluorescent DCFH into DCF, a highly fluorescent compound. Here, after irradiation, $2 \mathrm{mM} 5 \mu \mathrm{L}$ DCFH-DA were immediately added to $200 \mu \mathrm{L}$ of the irradiated samples and incubated at $37^{\circ} \mathrm{C}$ for $30 \mathrm{~min}$ in dark. The fluorescence of the samples was measured using a spectrofluorometer (SynergyTMH4, BioTek, USA) with the excitation wavelength of $488 \mathrm{~nm}$ and emission wave lengths between 500 and $600 \mathrm{~nm}$. The fluorescence intensity at $525 \mathrm{~nm}$, after subtraction of the fluorescence of blank control then normalizing to the protein content, was used to determine the relative ROS contents. Protein content was obtained by BCA protein assay kit (Thermo Scientific, USA).

\section{CELLS AND MAGNETOSOMES ANALYSES}

Morphologies of cells and magnetosome crystals of irradiated AMB-1 were analyzed using a JEOL JEM-1400 transmission electron microscope (TEM) with an accelerating voltage of $80 \mathrm{kV}$. About $20 \mu \mathrm{L}$ of cells were dropped onto a copper TEM grid covered with carbon-coated formvar film for $2 \mathrm{~h}$, then washed twice with sterilized distilled water and dried in air. Magnetosome sizes were defined as (length + width)/2, and the shape factors as width/length by measuring TEM micrographs.

For rock magnetic measurements, the cells were harvested by centrifugation at $4^{\circ} \mathrm{C}$. To prevent possible oxidation, the cell pellets were immediately transferred into a COY anaerobic chamber $\left[\left(\mathrm{O}_{2}\right)<300 \mathrm{ppm}\right.$, COY-7000220A, USA $]$ and loaded into nonmagnetic gelatin capsules and dried for overnight. The samples were stored in $-20^{\circ} \mathrm{C}$ with $\mathrm{N}_{2}$ protection prior to measurements (Li and Pan, 2012). Room temperature magnetic measurements were performed on a Model 3900 vibrating sample magnetometer (Princeton Measurements Corporation, USA, sensitivity $\left.5.0 \times 10^{-10} \mathrm{Am}^{2}\right)$. Hysteresis loops were measured between \pm $300 \mathrm{mT}$ in $3 \mathrm{mT}$ increments with $500 \mathrm{~ms}$ averaging time. The hysteresis parameters saturation magnetization $\left(M_{S}\right)$, saturation remanence $\left(M_{r s}\right)$, and coercivity $\left(B_{c}\right)$ were determined after paramagnetic correction. Remanence coercivity $\left(B_{c r}\right)$ was determined from a back-field demagnetization of the saturation isothermal remanent magnetization (SIRM) acquiring at $1.5 \mathrm{~T}$ field. Firstorder reversal curves (FORCs) were measured and calculated using the FORCinel version 1.22 software (Roberts et al., 2000; Harrison and Feinberg, 2008; Egli et al., 2010). The median coercivity $\left(B_{c}\right.$, FORC $)$ and half-width interaction field $\left(B_{b}, 1 / 2\right)$ were calculated (Muxworthy and Dunlop, 2002; Winklhofer and Zimanyi, 2006; Li et al., 2013b).

Low-temperature magnetic measurements were performed on a Quantum Design Magnetic Property Measurement System (MPMS XP-5). Zero-field cooling (ZFC) and field cooling (FC) curves were acquired by first cooling the samples from 300 to $10 \mathrm{~K}$ in a zero field and in a $2.5 \mathrm{~T}$ field, respectively, and then measuring the demagnetization of remanence in zero field during warming from 10 to $300 \mathrm{~K}$. The Verwey transition temperature $\left(T_{v}\right)$ were determined as the temperature for the maximum value of the first derivative of the FC curves. The $\delta$-ratio $\left(\delta_{\mathrm{FC}} / \delta_{\mathrm{ZFC}}\right)$, where $\delta=\left(M_{80 K}-M_{150 K}\right) / M_{80 K}$, were calculated according to Moskowitz et al. (1993).

\section{RESULTS}

\section{THE CELL GROWTH AFTER UV-B IRRADIATION}

The effect of UV-B radiation on cell growth indicates a clear dose dependence as revealed by $\mathrm{OD}_{600}$ (Figure 2). The initial $\mathrm{OD}_{600}$ values of all samples were about 0.025 after re-suspending

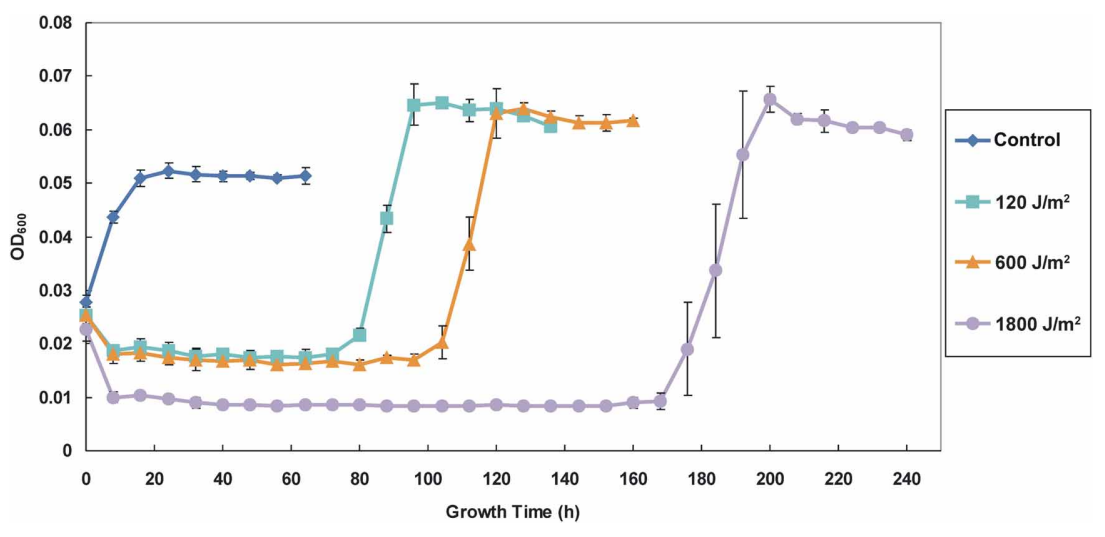

FIGURE 2 | Growth curves of the control (non-irradiated) and the irradiated AMB-1 cells. The diamond, square, triangle and circle shaped lines indicate the growth density (determine as $\mathrm{OD}_{600}$ ) of the control and irradiated cells after 120,600, and $1800 \mathrm{~J} / \mathrm{m}^{2} \mathrm{irradiation}$. 
the irradiated cells in fresh medium. After the first $8 \mathrm{~h}$ following re-suspension, the cell concentrations of the 120,600, and $1800 \mathrm{~J} / \mathrm{m}^{2}$ irradiated samples slightly decreased to 0.019 , 0.018 , and 0.01 , respectively, which indicates differing degrees of cell density loss. Subsequently, before they reached exponent growth phases and stationary phases, the irradiated samples remained relatively stable at low levels cell density (static phase or recovery time) for 72,96 , and $168 \mathrm{~h}$ for the groups received 120,600 , and $1800 \mathrm{~J} / \mathrm{m}^{2}$ irradiation, respectively. The non-irradiated control group exhibited rapid growth after resuspension and reached constant at stationary phase within $24 \mathrm{~h}$. We also note that the $1800 \mathrm{~J} / \mathrm{m}^{2}$ irradiation group had the longest recovery period and the largest standard deviation during growing at exponent phase, which suggests that the higher dose of irradiation might have caused more damage to cells in this group. Compared with the control group, all irradiated groups had a relatively higher $\mathrm{OD}_{600}$ in the stationary phase after recovery.

\section{VARIATIONS OF THE CPD FORMATION AND THE ROS ACCUMULATION}

As expected, UV-B radiation caused significant deleterious effects on DNA and cellular levels that correspond to the generation of CPD and the accumulation of ROS, respectively, which also exhibited dose-dependent patterns (Figure 3). CPD, induced by UV-B photons, is a photoproduct known as DNA lesions, which can blocks DNA replication and transcription. ROS is a collection of superoxide radical $\left(\mathrm{O}_{2}^{-}\right)$, hydroxylradial $\left(\mathrm{OH}^{\cdot}\right)$, hydrogen peroxide $\left(\mathrm{H}_{2} \mathrm{O}_{2}\right)$ and singlet oxygen $\left({ }^{1} \mathrm{O}_{2}\right)$ (He and Häder, 2002). These free radicals can lead to damages of lipids, proteins, and DNA. In our experiments, the strain AMB-1 exhibited distinct detrimental effects under different levels of UV-B irradiation.
Specifically, for the control, 120,600 , and $1800 \mathrm{~J} / \mathrm{m}^{2}$ groups, the amount of relative CPD generation were $0.118 \pm 0.018,0.133 \pm$ $0.037,0.599 \pm 0.023$, and $0.680 \pm 0.011$, while the ROS value reached $24.07 \pm 1.79,36.81 \pm 5.58,74.33 \pm 7.37$, and $98.66 \pm$ 1.22 (determined by normalized relative units), respectively.

\section{CHANGES OF THE CELL SIZE, MAGNETOSOMES AND CHAIN STRUCTURES}

The detailed information of the AMB-1 cells and magnetosomes after the bacteria recovered from UV-B irradiation are summarized in Table 1. Figures 4A-D are representative TEM micrographs of the AMB-1 cells of the four experiment groups. Interestingly, all UV-B irradiated cells produced larger grain sizes and longer magnetosome chains compared with the non-irradiated cells. Statistic analyses of each group indicate that the magnetosome grain size of the irradiated cells was nearly $10 \mathrm{~nm}$ larger on average than the non-irradiated cells. For the irradiated groups, we noticed decreased number of subchains per cell $\left(N_{s}\right)$, increased number of magnetosomes per cell $\left(N_{m}\right)$ and per subchain $\left(N_{s m}\right)$ (Table 2). However, the average cell lengths of the irradiated cells were about $0.4 \mu \mathrm{m}$ shorter than the control group. Although all irradiated samples had differences in cell size and magnetosome parameters, no clear dose-related change trend was observed.

\section{THE COERCIVITY, FORC DIAGRAMS AND $\delta$-RATIOS}

Magnetic properties of the whole cell samples were displayed in Table 2 and Figure 5. Consistent with previous studies on whole-cell MTB samples, all samples were characterized by Stoner-Wohlfath-type hysteresis loops with $M_{r s} / M_{s}$ ratio close to 0.5 (Stoner and Wohlfarth, 1948), and central-ridged FORC
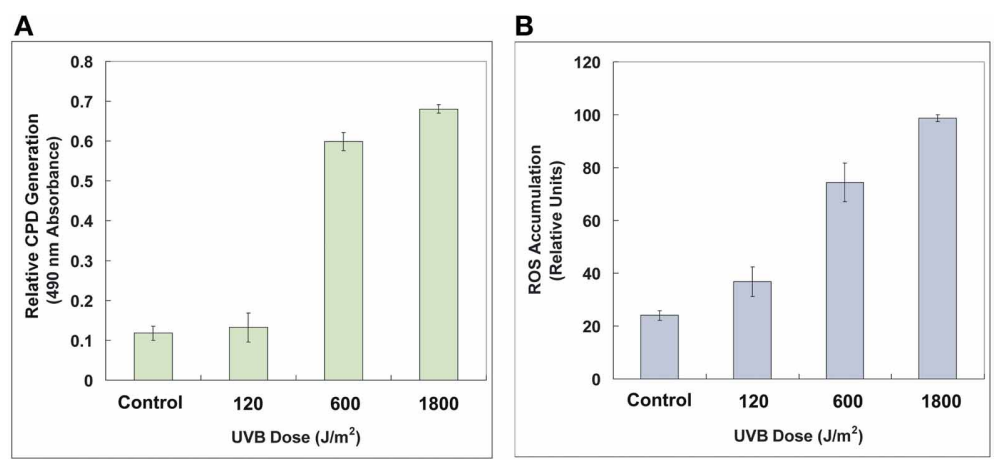

FIGURE 3 | Relative CPD generation (A) and ROS accumulation (B) of the control and the irradiated AMB-1 cells. The CPD formation was determined by $490 \mathrm{~nm}$ absorbance. The ROS content was characterized by $525 \mathrm{~nm}$ fluorescent intensity normalized protein content. See text for details.

Table 1 | Cell length, magnetosome, and subchain information of the AMB-1 samples at different irradiation levels.

\begin{tabular}{lllllrr}
\hline UV-B dose $\left(\mathbf{J} / \mathbf{m}^{2}\right)$ & Cell length $(\boldsymbol{\mu} \mathbf{m})$ & \multicolumn{3}{c}{ Magnetosome } & & \multicolumn{2}{c}{ Magnetosome chain } \\
\cline { 3 - 6 } & & Size $(\mathbf{n m})$ & Shape factor & $\boldsymbol{N}_{\boldsymbol{m}}$ (per cell) & $\boldsymbol{N}_{\boldsymbol{s}}$ (per cell) & $\boldsymbol{N}_{\boldsymbol{s m}}$ (per subchain) \\
\hline Control & $3.01 \pm 0.41$ & $45.44 \pm 10.31$ & $0.913 \pm 0.077$ & $11 \pm 3$ & $3 \pm 1$ & $3 \pm 2$ \\
120 & $2.64 \pm 0.65$ & $54.24 \pm 13.84$ & $0.860 \pm 0.088$ & $20 \pm 6$ & $2 \pm 1$ & $10 \pm 4$ \\
600 & $2.56 \pm 0.38$ & $55.43 \pm 14.43$ & $0.857 \pm 0.089$ & $19 \pm 5$ & $2 \pm 1$ & $9 \pm 3$ \\
1800 & $2.61 \pm 0.43$ & $55.79 \pm 13.78$ & $0.859 \pm 0.085$ & $21 \pm 5$ & $2 \pm 1$ & $10 \pm 4$
\end{tabular}




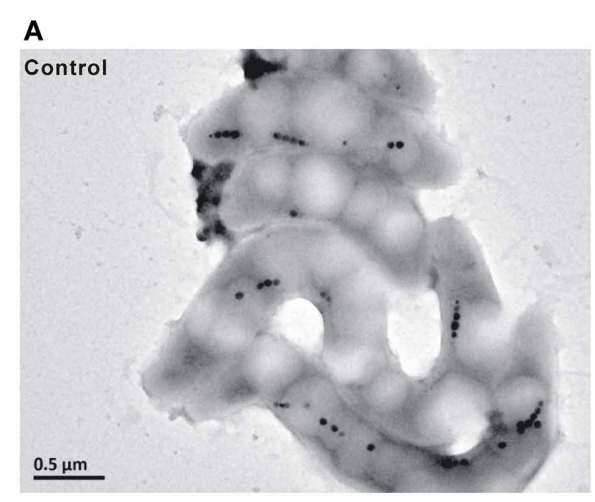

B

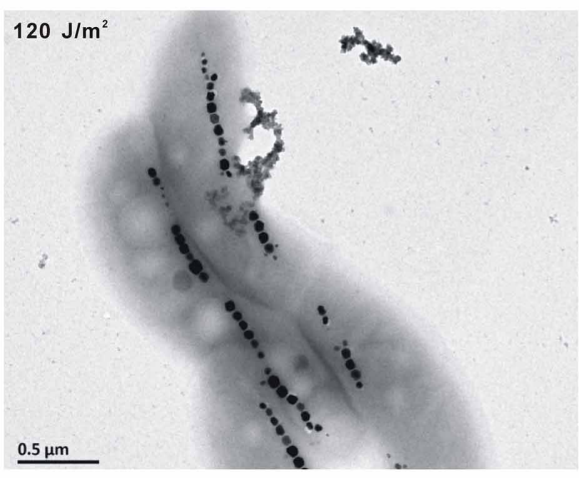

C

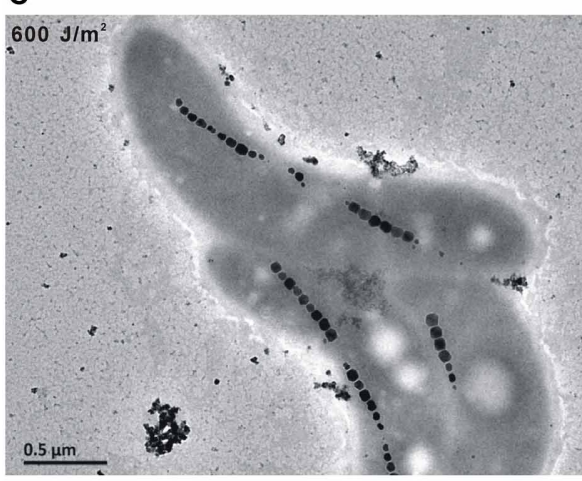

D

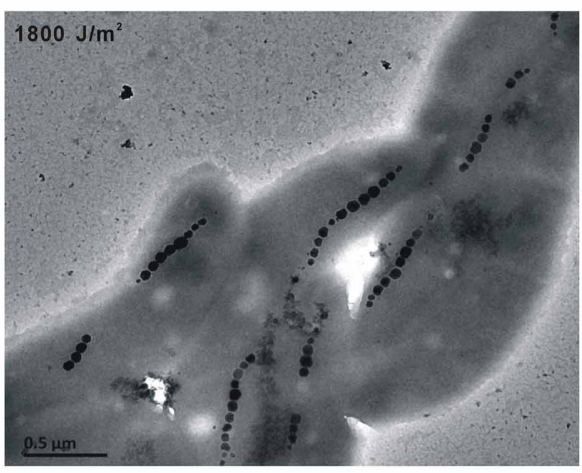

\section{E}

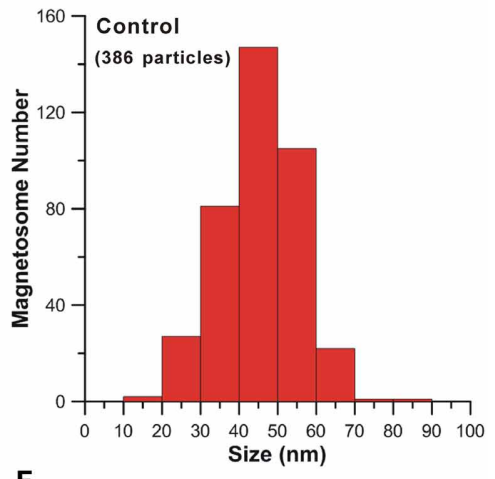

$\mathbf{F}$

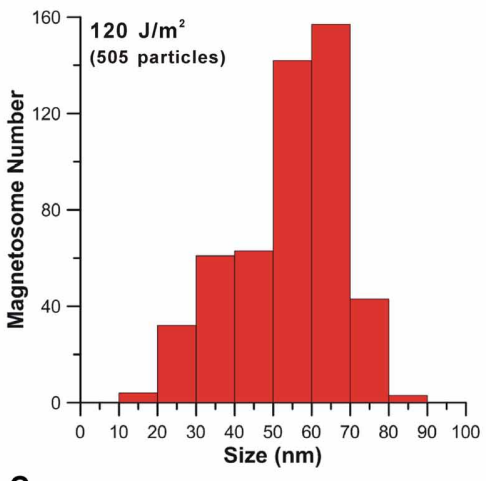

G

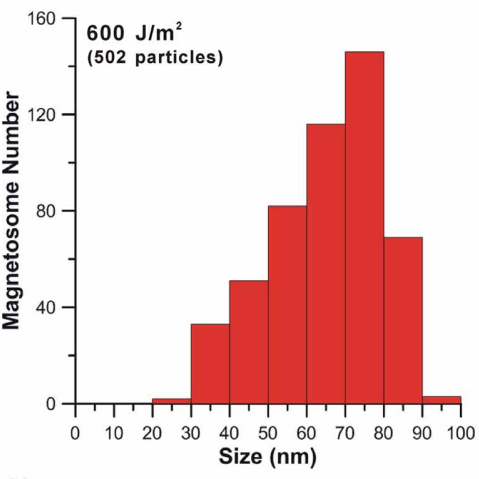

H

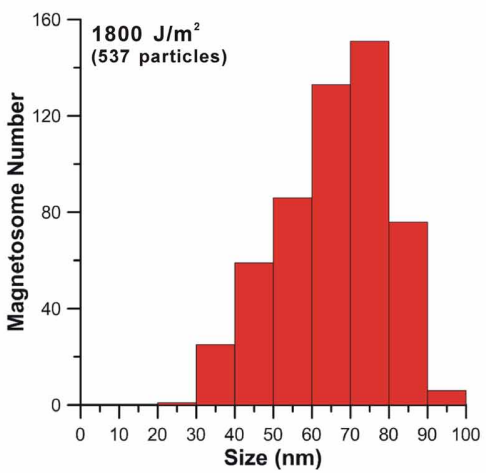

FIGURE 4 | TEM micrographs of cell morphology and magnetosome chains and histograms of magnetosome grain sizes of the control (A and E) and the irradiated AMB-1 cells (B-D and F-H). 
Table 2 | Magnetic parameters of the bulk AMB-1 samples at different irradiation levels.

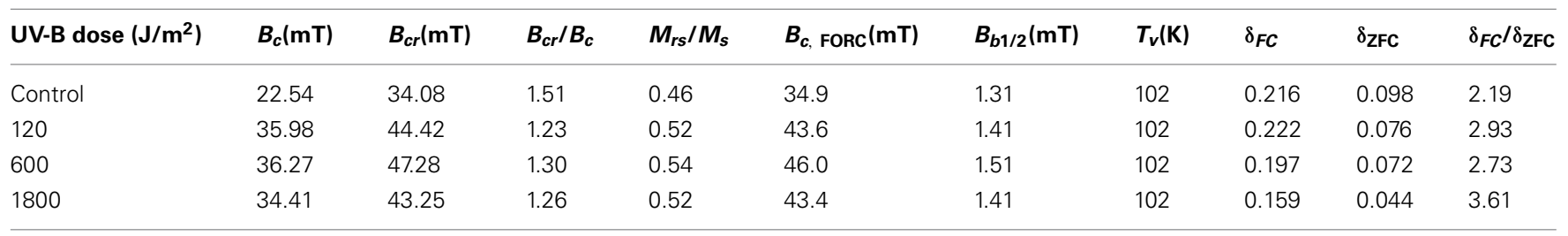
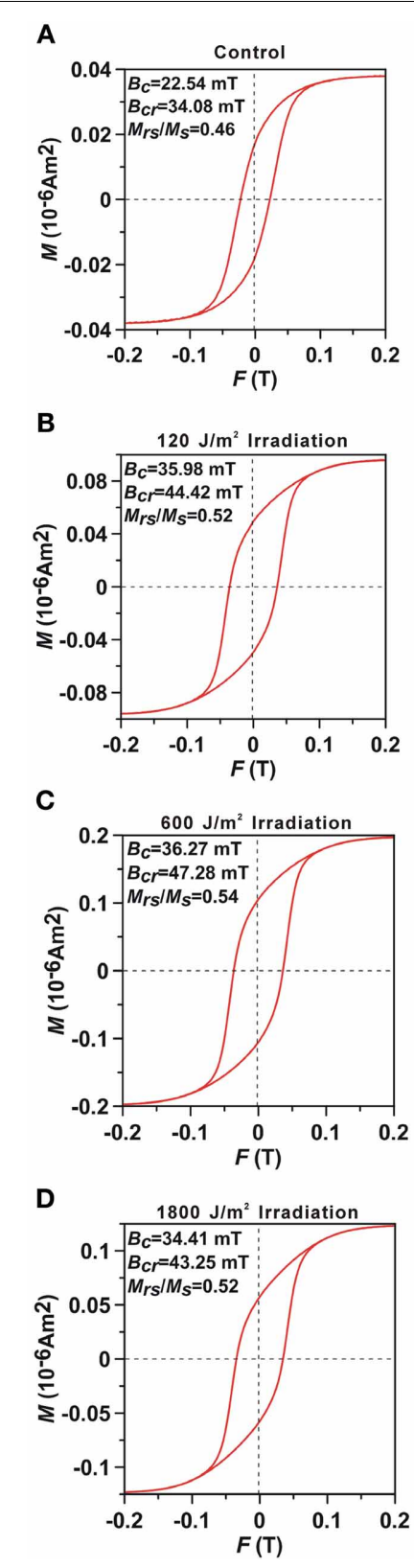
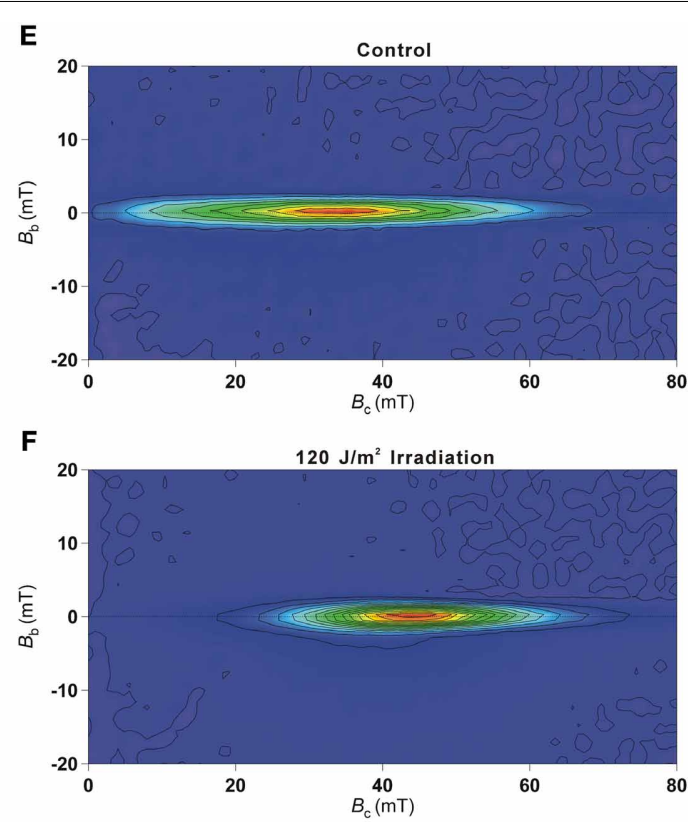

G
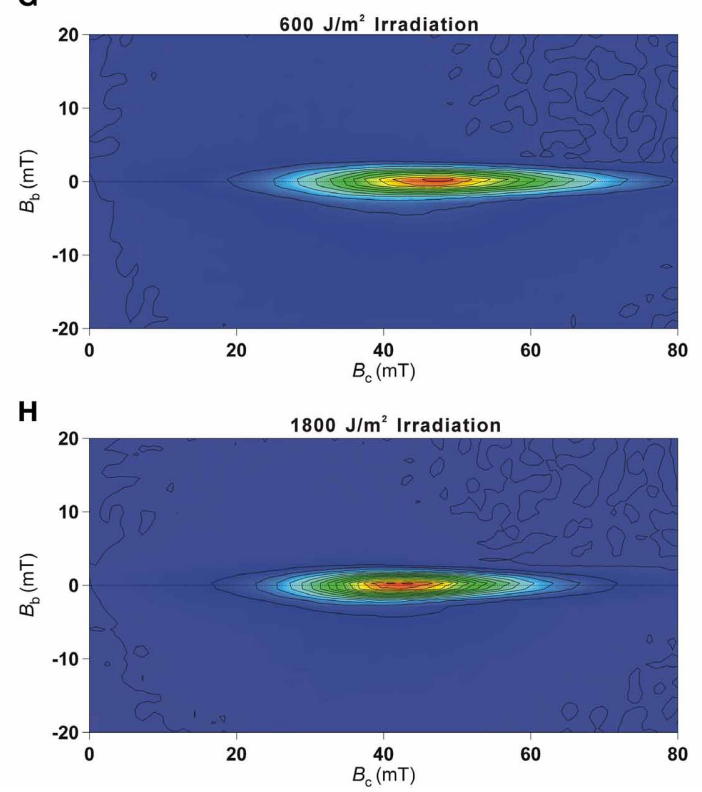

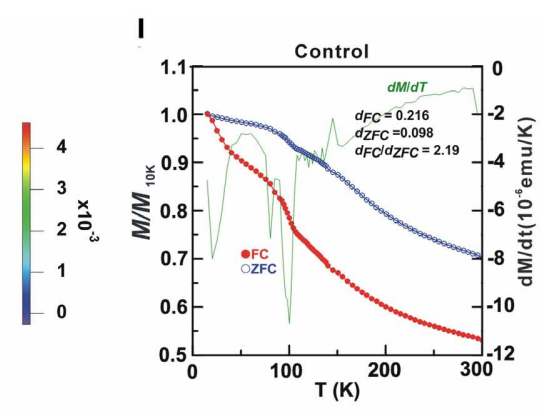

J

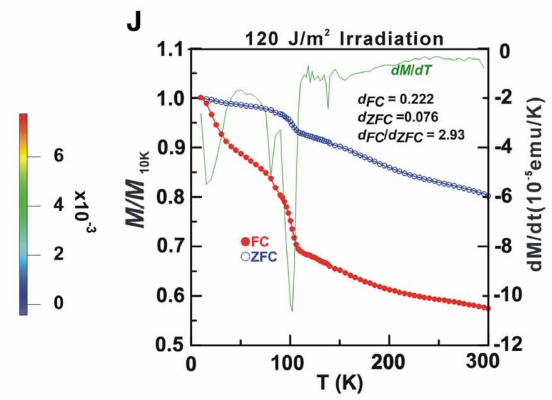

K

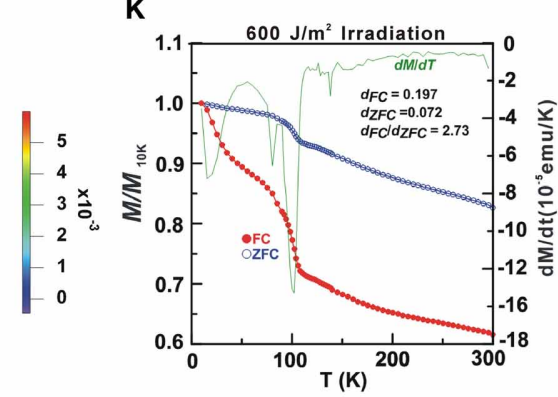

L

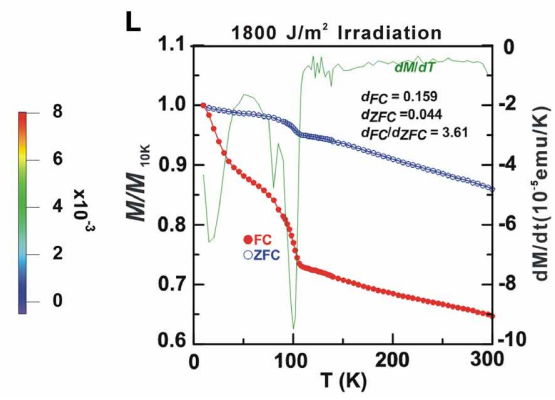

FIGURE 5 | Room temperature hysteresis loops (A-D), FORC diagrams (E-H) and low temperature magnetization curves (I-L) of the control and the irradiated cell bulk samples. In (I-L) the red, blue and green lines represent the FC, ZFC curves and first derivative of FC curves, respectively. 
diagrams characterized with a narrow distributed along $B_{c}$ axis (Figures 5E-H), indicating non-interacting uniaxial SD assemblages (Egli et al., 2010). In comparison, the room temperature magnetic parameters $B_{c}, B_{c r}$ and, $B_{c}$, FORC of the UV-B radiationtreated samples were nearly identical, but about $10 \mathrm{mT}$ higher than the control group. The decreased $B_{c r} / B_{c}$ values, increased $M_{r s} / M_{s}$ values and right-shifted FORCs suggest that the radiation treated samples possess magnetite crystals with larger grain sizes and/or longer chains, which have also been confirmed by the TEM observations (Figure 4).

Low-temperature measurements (Figures 5I-L) showed that the magnetic remanence of the UV-B radiation treated cells decreased rapidly at both $\sim 15-30$ and $\sim 102 \mathrm{~K}$ in FC curves. The $T_{v}$ of $102 \mathrm{~K}$ was similar to previous reports of magnetosome produced by strain AMB-1 (e.g., Li et al., 2009), which indicates no distinct change in the magnetosome composition by irradiation treatment. The $\delta$-ratio of the control, 120,600 , and $1800 \mathrm{~J} / \mathrm{m}^{2}$ irradiated samples were $2.10,2.93,2.73$, and 3.61, respectively, which further demonstrates better magnetosome chain structures in the radiation treated groups (Moskowitz et al., 1993).

\section{DISCUSSION \\ THE BIOLOGICAL DELETERIOUS EFFECTS OF UV-B IRRADIATION ON AMB-1 CELLS}

In this study, M. magneticum AMB-1 was used as a model organism to probe the UV-B biological effects on the cell growth and biomineralization. We found an initial decrease of cell density $\left(\mathrm{OD}_{600}\right)$ and a significant inhibition of growth of the AMB-1 after the bacteria were irradiated under doses of 120, 600, and $1800 \mathrm{~J} / \mathrm{m}^{2}$ (Figure 2). The increased CPD formation and the ROS accumulation (Figure 3) indicated clearly UV-B dose-dependent deleterious effects on both DNA and cellular levels after UV$\mathrm{B}$ irradiation. The self-repair after UV-B radiation might cause the observed prolonged static period of irradiated AMB-1 cells (Agogué et al., 2005; Goosen and Moolenaar, 2008). However, after the cells fully recovered $(40 \mathrm{~h}$ after reaching stationary growth phases), the accumulations of CPD were $0.075 \pm 0.007$, $0.086 \pm 0.027,0.092 \pm 0.036$ and $0.088 \pm 0.033$, and the ROS values were $31.45 \pm 5.48,25.76 \pm 3.56,30.04 \pm 8.31$, and $30.50 \pm$ 3.64 for the control, 120,600 , and $1800 \mathrm{~J} / \mathrm{m}^{2}$ irradiated groups, respectively. Those values of the irradiated groups were comparable to the non-irradiated control group, which suggests that AMB- 1 cells are able to repair the UV-B radiation damage.

Previous studies on repair strategies of aquatic organisms have demonstrated that after UV-B irradiation bacteria displayed a high efficient DNA light and dark repair to eliminate CPD that would block the replication and transcriptional process and lethiferous (Goosen and Moolenaar, 2008). For ROS that leads to cell membrane damage and cellular injuries, a series of antioxidant enzyme (e.g., superoxide dismutase, catalase, and peroxidase) can be induced to mitigate the negative effects caused by ROS (He and Häder, 2002; Xie et al., 2009; Santos et al., 2012). Transcriptome analysis of UV irradiated bacteria such as Deinococcus sp. and cyanobacterium Synechocystis also exhibited the up regulation of DNA repair and stress response-related genes. Both base/nucleotide excision repair and recombinational repair pathway participated in UV induced damage repair. Genes that were involved in scavenging oxygen radicals were also noticed up regulated after UV irradiation (Reid and Isaksen, 1976; Huang et al., 2002; Qiu et al., 2005a,b; Yuan et al., 2012).

Except for high efficiency removal of toxic oxygen species and specialized light and dark repair systems, other abilities (e.g., positive migration and production of UV screening pigments and compounds) can also help bacteria in avoiding harmful UV radiation (Ehling-Schulz and Scherer, 1999; Goosen and Moolenaar, 2008; Singh et al., 2010). Compared with non-magnetotactic bacteria in nature, MTB may migrate efficiently to deeper water layer or into sediments to avoid harmful UV radiation owing to their unique magnetotaxis. In addition, magnetite/greigite crystals may protect MTB from UV radiation.

\section{POSSIBLE EFFECTS ON MAGNETOSOME BIOMINERALIZATION}

TEM observations revealed that the irradiated cells, with a prolonged static phase, synthesized more and larger magnetosomes, as well as longer chains, which were further confirmed by various rock magnetic measurements. All irradiated samples had higher $B_{c}, B_{c r}, M_{s}, M_{r s}$ and $\delta$-ratio, and the FORC diagrams exhibited right shifts. Increased $B_{c}, B_{c r}$ and $B_{c}$, FORC were largely due to the increased magnetosome chain lengths and grain sizes, while higher $M_{s}$ and $M_{r s}$ were probably caused by increased magnetosome production, consistent with previous studies on magnetite particles within the SD range (Kobayashi et al., 2006; Kopp and Kirschvink, 2008; Li et al., 2009). When we reinoculated these irradiated but fully recovered cells into the same fresh medium once more, however, no enhancement of magnetosome biomineralization was detected in the stationary phases compared with the non-irradiated group. This suggests that the observed enhanced magnetite biomineralization maybe the regulation induced by irradiation rather than a genetic imprint or radiation selection under the used experimental condition for AMB-1. Some selfrepair processes and related metabolism changes may influence the crystallization of magnetosomes as well. At this stage, we cannot exclude that the prolonged recovery time of irradiated cells might affect the magnetite magnetosome formation.

Magnetite magnetosome biomineralization of MTB have been well documented by the molecular biologists and mineralogists (Bazylinski et al., 2007; Faivre and Schüler, 2008; Pósfai and Dunin-Borkowski, 2009). Previous studies have shown that biomineralization of chain arranged magnetite magnetosomes undergo several steps: formation of membrane vesicles on filamentary skeleton, iron uptake and magnetite crystallization within magnetosome membrane (Komeili, 2012). It has been found that the synthesis of magnetite magnetosome was closely related to nitrate reduction pathway (Bazylinski and Blakemore, 1983; Ge et al., 2011; Wang et al., 2011; Li et al., 2012). Iron and oxygen metabolism regulation also had significant influences on biomineralization of the cultured MSR-1 strain (Qi et al., 2012; Rong et al., 2012). Based on TEM micrographs, in addition to the magnetosome changes, the irradiated groups possess less round granules (possibly PHA which described by Keim et al., 2005; Silva et al., 2008) than the non-irradiated control group (data not shown). This is likely caused by the prolonged cell growth or some potential modification in the metabolism pathways within the irradiated cells. It also implies 
that the UV-B radiation may induce metabolism changes in AMB-1, which in turn affects magnetosome biomineralization. This suggestion is also supported by previous reports that UV radiation can strongly affect the metabolism of other microorganisms. For example, up regulated nitrate reduction genes such as nap and nos genes and genes related to iron-sequestering $(b p c$ and hem $\mathrm{H})$ and peroxide metabolism (e.g., oxy $\mathrm{R}, k a t \mathrm{G}$, and $\operatorname{sodB}$ ) were verified through transcriptome analyses of both radio-resistant bacterium Deinococcus species and a facultative anaerobic Gammaproteobacteria Shewanella oneidensis MR-1 after UV irradiation (Qiu et al., 2005a,b). Nevertheless, further investigations on time-series culture medium composition analyses and transcriptome of the irradiated AMB-1 cells are needed to reveal the mechanisms of these phenomena.

It is reasonable to assume that the enhanced biomineralization of magnetosomes in MTB may have some benefits for resistance of irradiation. The large size, number, and improved chain structures of magnetosomes in the MTB cell may greatly help bacteria to mitigate damage caused by UV-B. For example, the magnetosomes themselves are able to prevent the radiation and eliminate intracellular ROS (Guo et al., 2012). Moreover, the better magnetite magnetosome formation in cells may enhance the sensibility of magnetotaxis navigation to escape from UV exposure when magnetic field is low. A deep-branching group MTB, affiliating within the Nitrospira phylum, which contains a few hundred to a thousand bullet-shaped magnetite magnetosomes, are widely found in aquatic environments (Spring et al., 1993; Pan et al., 2005; Li et al., 2010; Jogler et al., 2011; Lin et al., 2012). Our new data support that the synthesis of large amount of magnetosomes within one cell might be significant evolutionary benefit for such MTB that lived on early Earth as the geomagnetic field was probably weak and the UV radiation was strong.

\section{ACKNOWLEDGMENTS}

We thank Haitao Chen for help in experiments of cell culture, Zuohan Peng and Jingyi Yang for cell damage analyses, and Greig A. Paterson for improving the language of this manuscript. This work was supported by the CAS/SAFEA International Partnership Program for Creative Research Teams (KZCX2-Yinzhao WangT10), the CAS project, and NSFC grants 41330104 and 41104041.

\section{SUPPLEMENTARY MATERIAL}

The Supplementary Material for this article can be found online at: http://www.frontiersin.org/journal/10.3389/ fmicb.2013.00397/abstract

\section{REFERENCES}

Agogué, H., Joux, F., Obernosterer, I., and Lebaron, P. (2005). Resistance of marine bacterioneuston to solar radiation. Appl. Environ. Microbiol. 71, 5282-5289. doi: 10.1128/AEM.71.9.5282-5289.2005

Arató, B., Szányi, Z., Flies, C., Schüler, D., Frankel, R. B., Buseck, P. R., et al. (2005). Crystal-size and shape distributions of magnetite from uncultured magnetotactic bacteria as a potential biomarker. Am. Mineral. 90, 1233-1240. doi: 10.2138/am.2005.1778

Bazylinski, D. A., and Blakemore, R. (1983). Denitrification and assimilatory nitrate reduction in Aquaspirillum magnetotacticum. Appl. Environ. Microbiol. 46, 1118-1124.

Bazylinski, D. A., and Frankel, R. B. (2004). Magnetosome formation in prokaryotes. Nat. Rev. Microbiol. 2, 217-230. doi: 10.1038/nrmicro842
Bazylinski, D. A., Frankel, R. B., and Konhauser, K. O. (2007). Modes of biomineralization of magnetite by microbes. Geomicrobiol. J. 24, 465-475. doi: 10.1080/01490450701572259

Blakemore, R., Maratea, D., and Wolfe, R. (1979). Isolation and pure culture of a freshwater magnetic spirillum in chemically defined medium. J. Bacteriol. 140, 720-729.

Chang, S. B. R., and Kirschvink, J. L. (1989). Magnetofossils, the magnetization of sediments, and the evolution of magnetite biomineralization. Annu. Rev. Earth Planet. Sci. 17, 169. doi: 10.1146/annurev.ea.17.050189.001125

Cockell, C. S. (1998). Biological effects of high ultraviolet radiation on early Earth-a theoretical evaluation. J. Theor. Biol. 193, 717-729. doi: 10.1006/jtbi.1998.0738

Egli, R., Chen, A. P., Winklhofer, M., Kodama, K. P., and Horng, C. S. (2010). Detection of noninteracting single domain particles using firstorder reversal curve diagrams. Geochem. Geophys. Geosyst. 11, Q01Z11. doi: 10.1029/2009GC002916

Ehling-Schulz, M., and Scherer, S. (1999). UV protection in cyanobacteria. Eur. J. Phycol. 34, 329-338. doi: 10.1080/09670269910001736392

Faivre, D., Menguy, N., Pósfai, M., and Schüler, D. (2008). Environmental parameters affect the physical properties of fast-growing magnetosomes. Am. Mineral. 93, 463-469. doi: 10.2138/am.2008.2678

Faivre, D., and Schüler, D. (2008). Magnetotactic bacteria and magnetosomes. Chem. Rev. 108, 4875. doi: 10.1021/cr078258w

Garcia-Pichel, F. (1998). Solar ultraviolet and the evolutionary history of cyanobacteria. Orig. Life Evol. Biosph. 28, 321-347. doi: 10.1023/A:1006545303412

Ge, X., Wang, K., Bo, T., Kou, Y., Liu, W., and Chen, G. (2011). Magnetospirillum magneticum AMB-1 peroxiredoxins contribute to the aerotolerance and genetic stability of the genomic magnetosome island. FEMS Microbiol. Lett. 320, 118-127. doi: 10.1111/j.1574-6968.2011.02298.x

Glassmeier, K. H., and Vogt, J. (2010). Magnetic polarity transitions and biospheric effects. Space Sci. Rev. 155, 387-410. doi: 10.1007/s11214-010-9659-6

Goosen, N., and Moolenaar, G. F. (2008). Repair of UV damage in bacteria. DNA Repair 7, 353-379. doi: 10.1016/j.dnarep.2007.09.002

Guo, F. F., Yang, W., Jiang, W., Geng, S., Peng, T., and Li, J. L. (2012). Magnetosomes eliminate intracellular reactive oxygen species in Magnetospirillum gryphiswaldense MSR-1. Environ. Microbiol. 14, 1722-1729. doi: 10.1111/j.1462-2920.2012.02707.x

Häder, D. P., Kumar, H., Smith, R., and Worrest, R. (2007). Effects of solar UV radiation on aquatic ecosystems and interactions with climate change. Photochem. Photobiol. Sci. 6, 267-285. doi: 10.1039/b700020k

Hargreaves, B. R. (2003). "Water column optics and penetration of UVR," in UV Effects in Aquatic Organisms and Ecosystems, eds E. W. Helbling and H. Zagarese (London: The Royal Society of Chemistry), 59-105. doi: 10.1039/9781847552266-00059

Harrison, R. J., and Feinberg. J. M. (2008). FORCinel: an improved algorithm for calculating first-order reversal curve distributions using locally weighted regression smoothing. Geochem. Geophys. Geosyst. 9, Q05016. doi: 10.1029/ 2008GC001987

He, Y. Y., and Häder, D. P. (2002). Involvement of reactive oxygen species in the UV-B damage to the cyanobacterium Anabaena sp. J. Photochem. Photobiol. B 66, 73-80. doi: 10.1016/S1011-1344(01)00278-0

Hernandez, E. A., Ferreyra, G. A., and Mac Cormack, W. P. (2006). Response of two Antarctic marine bacteria to different natural UV radiation doses and wavelengths. Antarct. Sci. 18, 205-212. doi: 10.1017/S0954102006000241

Huang, L., McCluskey, M. P., Ni, H., and LaRossa, R. A. (2002). Global gene expression profiles of the cyanobacterium Synechocystis sp. strain PCC 6803 in response to irradiation with UV-B and white light. J. Bacteriol. 184, 6845-6858. doi: 10.1128/JB.184.24.6845-6858.2002

Jogler, C., Wanner, G., Kolinko, S., Niebler, M., Amann, R., Petersen, N., et al. (2011). Conservation of proteobacterial magnetosome genes and structures in an uncultivated member of the deep-branching Nitrospira phylum. Proc. Natl. Acad. Sci. U.S.A. 108, 1134-1139. doi: 10.1073/pnas. 1012694108

Keim, C. N., Solórzano, G., Farina, M., and Lins, U. (2005). Intracellular inclusions of uncultured magnetotactic bacteria. Int. Microbiol. 8, 111-117.

Kobayashi, A., Kirschvink, J. L., Nash, C. Z., Kopp, R. E., Sauer, D. A., Bertani, L. E., et al. (2006). Experimental observation of magnetosome chain collapse in magnetotactic bacteria: sedimentological, paleomagnetic, and evolutionary implications. Earth Planet. Sci. Lett. 245, 538-550. doi: 10.1016/j.epsl.2006.03.041 
Komeili, A. (2012). Molecular mechanisms of compartmentalization and biomineralization in magnetotactic bacteria. FEMS Microbiol. Rev. 36, 232-255. doi: 10.1111/j.1574-6976.2011.00315.x

Konhauser, K. O., Amskold, L., Lalonde, S. V., Posth, N. R., Kappler, A., and Anbar, A. (2007). Decoupling photochemical Fe (II) oxidation from shallowwater BIF deposition. Earth Planet. Sci. Lett. 258, 87-100. doi: 10.1016/j.epsl. 2007.03.026

Kopp, R. E., and Kirschvink, J. L. (2008). The identification and biogeochemical interpretation of fossil magnetotactic bacteria. Earth Sci. Rev. 86, 42-61. doi: 10.1016/j.earscirev.2007.08.001

Li, J., Benzerara, K., Bernard, S., and Beyssac, O. (2013a). The link between biomineralization and fossilization of bacteria: insights from field and experimental studies. Chem. Geol. 359, 49-69. doi: 10.1016/j.chemgeo.2013.09.013

Li, J., Ge, K., Pan, Y., Williams, W., Liu, Q., and Qin, H. (2013b). A strong angular dependence of magnetic properties of magnetosome chains: implications for rock magnetism and paleomagnetism. Geochem. Geophys. Geosyst. 14, 3887-3907. doi: 10.1002/ggge.20228

Li, J., and Pan, Y. (2012). Environmental factors affect magnetite magnetosome synthesis in Magnetospirillum magneticum AMB-1: implications for biologically controlled mineralization. Geomicrobiol. J. 29, 362-373. doi: 10.1080/01490451.2011.565401

Li, J., Pan, Y., Chen, G., Liu, Q., Tian, L., and Lin, W. (2009). Magnetite magnetosome and fragmental chain formation of Magnetospirillum magneticum AMB-1: transmission electron microscopy and magnetic observations. Geophys. J. Int. 177, 33-42. doi: 10.1111/j.1365-246X.2009.04043.x

Li, J., Pan, Y., Liu, Q., Yu-Zhang, K., Menguy, N., Che, R., et al. (2010). Biomineralization, crystallography and magnetic properties of bullet-shaped magnetite magnetosomes in giant rod magnetotactic bacteria. Earth Planet. Sci. Lett. 293, 368-376. doi: 10.1016/j.epsl.2010.03.007

Li, Y., Katzmann, E., Borg, S., and Schüler, D. (2012). The periplasmic nitrate reductase Nap is required for anaerobic growth and involved in redox control of magnetite biomineralization in Magnetospirillum gryphiswaldense. J. Bacteriol. 194, 4847-4856. doi: 10.1128/JB.00903-12

Lin, W., Li, J., and Pan, Y. (2012). Newly isolated but uncultivated magnetotactic bacterium of the phylum Nitrospirae from Beijing, China. Appl. Environ. Microbiol. 78, 668-675. doi: 10.1128/AEM.06764-11

Lin, W., Wang, Y., Gorby, Y., Nealson, K., and Pan, Y. (2013a). Integrating nichebased process and spatial process in biogeography of magnetotactic bacteria. Sci. Rep. 3, 1643. doi: 10.1038/srep01643

Lin, W., Bazylinski, D. A., Xiao, T., Wu, L. F., and Pan, Y. (2013b). Life with compass: diversity and biogeography of magnetotactic bacteria. Environ. Microbiol. doi: 10.1111/1462-2920.12313. [Epub ahead of print].

Lin, W., Wang, Y., Li, B., and Pan, Y. (2011). A biogeographic distribution of magnetotactic bacteria influenced by salinity. ISME J. 6, 475-479. doi: 10.1038/ismej.2011.112

Lins, U., Keim, C. N., Evans, F. F., Farina, M., and Buseck, P. R. (2007). Magnetite $\left(\mathrm{Fe}_{3} \mathrm{O}_{4}\right)$ and greigite $\left(\mathrm{Fe}_{3} \mathrm{~S}_{4}\right)$ crystals in multicellular magnetotactic prokaryotes. Geomicrobiol. J. 24, 43-50. doi: 10.1080/01490450601 134317

Mandal, S., Rath, J., and Adhikary, S. P. (2011). Adaptation strategies of the sheathed cyanobacterium Lyngbya majuscula to ultraviolet-B. J. Photochem. Photobiol. B 102, 115-122. doi: 10.1016/j.jphotobiol.2010. 09.011

Matallana-Surget, S., Joux, F., Wattiez, R., and Lebaron, P. (2012). Proteome analysis of the UVB-resistant marine bacterium Photobacterium angustum S14. PLoS ONE 7:e42299. doi: 10.1371/journal.pone.0042299

McKay, D. S., Gibson, E. K., Thomas-Keprta, K. L., Vali, H., Romanek, C. S., Clemett, S. J., et al. (1996). Search for past life on Mars: possible relic biogenic activity in Martian meteorite ALH84001. Science 273, 924-930. doi: 10.1126/science.273.5277.924

McKenzie, R. L., Björn, L. O., Bais, A., and Ilyasd, M. (2003). Changes in biologically active ultraviolet radiation reaching the Earth's surface. Photochem. Photobioll. Sci. 2, 5-15. doi: 10.1039/b211155c

Moskowitz, B. M., Frankel, R. B., and Bazylinski, D. A. (1993). Rock magnetic criteria for the detection of biogenic magnetite. Earth Planet. Sci. Lett. 120, 283-300. doi: 10.1016/0012-821X(93)90245-5

Muxworthy, A. R., and Dunlop, D. J. (2002). First-order reversal curve (FORC) diagrams for pseudo-single-domain magnetites at high temperature. Earth Planet. Sci. Lett. 203, 369-382. doi: 10.1016/S0012-821X(02)00880-4
Pan, Y., Lin, W., Li, J., Wu, W., Tian, L., Deng, C., et al. (2009). Reduced efficiency of magnetotaxis in magnetotactic coccoid bacteria in higher than geomagnetic fields. Biophysic. J. 97, 986-991. doi: 10.1016/j.bpj.2009.06.012

Pan, Y., Petersen, N., Davila, A. F., Zhang, L., Winklhofer, M., Liu, Q., et al. (2005). The detection of bacterial magnetite in recent sediments of Lake Chiemsee (southern Germany). Earth Planet. Sci. Lett. 232, 109-123. doi: 10.1016/j.epsl.2005.01.006

Paterson, A. G., Wang, Y., and Pan, Y. (2013). The fidelity of paleomagnetic records carried by magnetosome chains. Earth Planet. Sci. Lett. 383, 82-91. doi: 10.1016/j.epsl.2013.09.031

Petersen, N., von Dobeneck, T., and Vali, H. (1986). Fossil bacterial magnetite in deep-sea sediments from the South Atlantic Ocean. Nature 320, 611-615. doi: $10.1038 / 320611 \mathrm{a} 0$

Phoenix, V., Konhauser, K., Adams, D., and Bottrell, S. (2001). Role of biomineralization as an ultraviolet shield: implications for Archean life. Geology 29, 823-826. doi: 10.1130/0091-7613(2001)029<0823:ROBAAU > 2.0.CO;2

Pósfai, M., and Dunin-Borkowski, R. E. (2009). Magnetic nanocrystals in organisms. Elements 5, 235-240. doi: 10.2113/gselements.5.4.235

Qi, L., Li, J., Zhang, W., Liu, J., Rong, C., Li, Y., et al. (2012). Fur in Magnetospirillum gryphiswaldense influences magnetosomes formation and directly regulates the genes involved in iron and oxygen metabolism. PLoS ONE 7:e29572. doi: 10.1371/journal.pone.0029572

Qiu, X., Tiedje, J. M., and Sundin, G. W. (2005a). Genome-wide examination of the natural solar radiation response in Shewanella oneidensis MR-1. Photochem. Photobiol. 81, 1559-1568. doi: 10.1562/2005-04-15-RA-490

Qiu, X., Sundin, G. W., Wu, L., Zhou, J., and Tiedje, J. M. (2005b). Comparative analysis of differentially expressed genes in Shewanella oneidensis MR-1 following exposure to UVC, UVB, and UVA radiation. J. Bacteriol. 187, 3556-3564. doi: 10.1128/JB.187.10.3556-3564.2005

Reid, G., and Isaksen, I. (1976). Influence of ancient solar-proton events on the evolution of life. Nature 259, 177-179. doi: 10.1038/259177a0

Roberts, A. P., Pike, C. R., and Verosub, K. L. (2000). First-order reversal curve diagrams: a new tool for characterizing the magnetic properties of natural samples. J. Geophys. Res. Solid Earth. 105, 28461-28476. doi: 10.1029/2000JB900326

Rong, C., Zhang, C., Zhang, Y., Qi, L., Yang, J., Guan, G., et al. (2012). FeoB2 functions in magnetosome formation and oxidative stress protection in Magnetospirillum gryphiswaldense strain MSR-1. J. Bacteriol. 194, 3972-3976. doi: 10.1128/JB.00382-12

Santos, A., Lopes, S., Baptista, I., Henriques, I., Gomes, N., Almeida, A., et al. (2011). Diversity in UV sensitivity and recovery potential among bacterioneuston and bacterioplankton isolates. Lett. Appl. Microbiol. 52, 360-366. doi: 10.1111/j.1472-765X.2011.03011.x

Santos, A. L., Gomes, N., Henriques, I., Almeida, A., Correia, A., and Cunha, Â. (2012). Contribution of reactive oxygen species to UV-Binduced damage in bacteria. J. Photochem. Photobiol. B 117, 40-46. doi: 10.1016/j.jphotobiol.2012.08.016

Santos, A. L., Oliveira, V., Baptista, I., Henriques, I., Gomes, N. C., Almeida, A., et al. (2013). Wavelength dependence of biological damage induced by UV radiation on bacteria. Arch. Microbiol. 195, 63-74. doi: 10.1007/s00203-012-0847-5

Schmidt, É. C., Scariot, L. A., Rover, T., and Bouzon, Z. L. (2009). Changes in ultrastructure and histochemistry of two red macroalgae strains of Kappaphycus alvarezii (Rhodophyta, Gigartinales), as a consequence of ultraviolet B radiation exposure. Micron 40, 860-869. doi: 10.1016/j.micron.2009.06.003

Silva, K. T., Abreu, F., Keim, C. N., Farina, M., and Lins, U. (2008). Ultrastructure and cytochemistry of lipid granules in the many-celled magnetotactic prokaryote, Candidatus Magnetoglobus multicellularis. Micron 39, 1387-1392. doi: 10.1016/j.micron.2008.05.009

Singh, S. P., Häder, D. P., and Sinha, R. P. (2010). Cyanobacteria and ultraviolet radiation (UVR) stress: mitigation strategies. Ageing Res. Rev. 9, 79-90. doi: 10.1016/j.arr.2009.05.004

Singh, V. P., Srivastava, P. K., and Prasad, S. M. (2012). Impact of low and high fluence rates of UV-B radiation on growth and oxidative stress in Phormidium foveolarum and Nostoc muscorum under copper toxicity: differential display of antioxidants system. Acta Physiol. Plant. 34, 2225-2239. doi: 10.1007/s11738012-1023-x

Sinha, R. P., and Häder, D. P. (2008). UV-protectants in cyanobacteria. Plant Sci. 174, 278-289. doi: 10.1016/j.plantsci.2007.12.004

Solomon, S. (1999). Stratospheric ozone depletion: a review of concepts and history. Rev. Geophys. 37, 275-316. doi: 10.1029/1999RG900008 
Spring, S., Amann, R., Ludwig, W., Schleifer, K. H., van Gemerden, H., and Petersen, N. (1993). Dominating role of an unusual magnetotactic bacterium in the microaerobic zone of a freshwater sediment. Appl. Environ. Microbiol. 59, 2397-2403.

Stadelmann, A., Vogt, J., Glassmeier, K. H., Kallenrode, M. B., and Voigt, G. H. (2010). Cosmic ray and solar energetic particle flux in paleomagnetospheres. Earth Planets Space 62, 333. doi: 10.5047/eps.2009.10.002

Stoner, E. C., and Wohlfarth, E. (1948). A mechanism of magnetic hysteresis in heterogeneous alloys. Philos. T. R. Soc. A. 240, 599-642. doi: 10.1098/rsta.1948. 0007

Valet, J. P., and Valladas, H. (2010). The Laschamp-Mono lake geomagnetic events and the extinction of Neanderthal: a causal link or a coincidence? Quaternary Sci. Rev. 29, 3887-3893. doi: 10.1016/j.quascirev.2010.09.010

Wang, K., Ge, X., Bo, T., Chen, Q., Chen, G., and Liu, W. (2011). Interruption of the denitrification pathway influences cell growth and magnetosome formation in Magnetospirillum magneticum AMB-1. Lett. Appl. Microbiol. 53, 55-62. doi: 10.1111/j.1472-765X.2011.03063.x

Wang, Y., Lin, W., Li, J., and Pan, Y. (2013). High diversity of magnetotactic deltaproteobacteria in a freshwater niche. Appl. Environ. Microbiol. 79, 2813-2817. doi: 10.1128/AEM.03635-12

Weigand, M. R., and Sundin, G. W. (2009). Long-term effects of inducible mutagenic DNA repair on relative fitness and phenotypic diversification in Pseudomonas cichorii 302959. Genetics 181, 199-208. doi: 10.1534/genetics.108.096131

Weigand, M. R., and Sundin, G. W. (2012). General and inducible hypermutation facilitate parallel adaptation in Pseudomonas aeruginosa despite divergent mutation spectra. Proc. Natl. Acad. Sci. U.S.A. 109, 13680-13685. doi: 10.1073/pnas.1205357109

Weigand, M. R., Tran, V. N., and Sundin, G. W. (2011). Growth parameter components of adaptive specificity during experimental evolution of the uvr-inducible mutator Pseudomonas cichorii 302959. PLoS ONE 6:e15975. doi: 10.1371/journal.pone.0015975

Winklhofer, M., and Zimanyi, G. T. (2006). Extracting the intrinsic switching field distribution in perpendicular media: a comparative analysis. J. Appl. Phys. 99, 08E710-708E713. doi: 10.1063/1.2176598

Wulff, A., Roleda, M., Zacher, K., and Wiencke, C. (2008). UV radiation effects on pigments, photosynthetic efficiency and DNA of an Antarctic marine benthic diatom community. Aquat. Biol. 3, 167-177. doi: 10.3354/ ab00076

Xie, Z., Wang, Y., Liu, Y., and Liu, Y. (2009). Ultraviolet-B exposure induces photo-oxidative damage and subsequent repair strategies in a desert cyanobacterium Microcoleus vaginatus. Gom. Eur. J. Soil Biol. 45, 377-382. doi: 10.1016/j.ejsobi.2009.04.003

Yamazaki, T., and Kawahata, H. (1998). Organic carbon flux controls the morphology of magnetofossils in marine sediments. Geology 26, 1064-1066.

Yuan, M., Chen, M., Zhang, W., Lu, W., Wang, J., Yang, M., et al. (2012). Genome sequence and transcriptome analysis of the radioresistant bacterium Deinococcus gobiensis: insights into the extreme environmental adaptations. PLOS ONE 7:e34458. doi: 10.1371/journal.pone. 0034458

Zenoff, V. F., Sineriz, F., and Farías, M. (2006). Diverse responses to UV-B radiation and repair mechanisms of bacteria isolated from high-altitude aquatic environments. Appl. Environ. Microbiol. 72, 7857-7863. doi: 10.1128/AEM.01333-06

Zepp, R. G., Callaghan, T., and Erickson, D. (1998). Effects of enhanced solar ultraviolet radiation on biogeochemical cycles. J. Photochem. Photobiol. B 46, 69-82. doi: 10.1016/S1011-1344(98)00186-9

Conflict of Interest Statement: The authors declare that the research was conducted in the absence of any commercial or financial relationships that could be construed as a potential conflict of interest.

Received: 21 October 2013; accepted: 04 December 2013; published online: 19 December 2013.

Citation: Wang Y, Lin W, Li J and Pan Y (2013) Changes of cell growth and magnetosome biomineralization in Magnetospirillum magneticum AMB-1 after ultraviolet- $B$ irradiation. Front. Microbiol. 4:397. doi: 10.3389/fmicb.2013.00397

This article was submitted to Aquatic Microbiology, a section of the journal Frontiers in Microbiology.

Copyright (c) 2013 Wang, Lin, Li and Pan. This is an open-access article distributed under the terms of the Creative Commons Attribution License (CC BY). The use, distribution or reproduction in other forums is permitted, provided the original author(s) or licensor are credited and that the original publication in this journal is cited, in accordance with accepted academic practice. No use, distribution or reproduction is permitted which does not comply with these terms. 